\title{
The endogenous feeding suppressant, 2-buten-4-olide, impairs the pulsatile secretion of luteinizing hormone through endogenous opioid peptides
}

\author{
Hiroyuki Kaji, Seiichiro Saito, Keiji Shitsukawa, Minoru Irahara and Toshihiro Aono \\ Department of Obstetrics and Gynecology, The University of Tokushima School of Medicine, Tokushima, Japan \\ (Correspondence should be addressed to H Kaji, Department of Obstetrics and Gynecology, The University of Tokushima, School of Medicine, \\ 3-18-15, Kuramoto-cho Tokushima City, Tokushima 770, Japan)
}

\begin{abstract}
Objective: To clarify the mechanism of the suppressive effect of 2-buten-4-olide (2-B4O), an endogenous feeding suppressant, on the pulsatile secretion of luteinizing hormone (LH), by studying whether endogenous opioid peptides are involved in this suppressive effect.

Methods: Using ovariectomized (ovx) rats, blood samples were taken every 6 min for $2 \mathrm{~h}$ after administration of 2-B4O or saline into the third cerebroventricle $(3 \mathrm{~V})$ and sequential i.v. injection of naloxone $(0.5 \mathrm{mg} / \mathrm{kg}$ per $\mathrm{h})$ or saline. Rats were divided into three experimental groups: group 1: $3 \mathrm{~V}$ saline + i.v. saline (control); group 2: 3V 2-B4O + i.v. saline; group 3: 3V 2-B4O+i.v. naloxone. Serum LH concentrations were determined by double-antibody RIA. To determine whether 2-B4O affected the biosynthetic activity of the opioidergic neurons within the ovx rat arcuate nucleus, we measured the concentrations of pro-opiomelanocortin (POMC) mRNA, a precursor of $\beta$-endorphin, in the rostral arcuate nucleus using non-radioactive in situ hybridization and a computerized image-analysis system. Results: 2-B4O significantly suppressed the pulse frequency of LH (group 2: $1.5 \pm 0.33$ pulses/2 h, group 1: $2.43 \pm 0.2$ pulses $/ 2 \mathrm{~h} ; P<0.05$ ), but naloxone blocked its suppressive effect and restored the pulse frequency (group 3: $3.29 \pm 0.36$ pulses $/ 2 \mathrm{~h}$, group 2: $1.5 \pm 0.33$ pulses $/ 2 \mathrm{~h} ; P<0.01$ ). There were no significant changes in the mean LH concentrations and amplitude. Furthermore, 2-B4O significantly stimulated the expression of POMC mRNA in the rostral arcuate nucleus.

Conclusion: These results suggest that 2-B4O may impair the pulsatile secretion of LH by activating the opioid pathway within the hypothalamus.
\end{abstract}

European Journal of Endocrinology 138 198-205

\section{Introduction}

Reduced food intake is known to be associated with reproductive dysfunction in humans $(1,2)$, and rats (3$5)$. Several kinds of endogenous sugar acids found in rat blood have been reported to be involved in control of food intake $(6,7)$. It has been demonstrated that 2-buten-4-olide (2-B4O), which is one of the endogenous sugar acids and starts to increase $24 \mathrm{~h}$ after fasting in the blood of rats (8), induces a sensation of satiety and strongly suppresses feeding by i.p., i.v., third cerebroventricle $(3 \mathrm{~V})$ and intragastric administration (9). It has also been suggested that the action of 2-B40 on food intake is mediated through glucose-sensitive neurons in the lateral hypothalamic area, a feeding center, and glucoreceptor neurons in the ventromedial hypothalamic nucleus of the hypothalamus, a satiety center (9).

Shitsukawa et al. (10) reported that administration of 2-B4O induced disturbance of the estrous cycle and a decrease in the serum concentration of luteinizing hormone (LH) in intact rats. Saito et al. (11) also reported that administration of 2-B40 reduced the pulsatile secretion of LH from the pituitary in ovariectomized (ovx) rats. These results indicated that 2-B4O might impair the hypothalamic function, because the pulsatile secretion of LH is known to be maintained by gonadotropin-releasing hormone $(\mathrm{GnRH})$ release. The mechanism of such an effect remains unclear.

There is general agreement that endogenous opioid peptides (EOPs) exert a suppressive effect on $\mathrm{LH}$ secretion. There are some reports (3-5) that fasting impairs the pulsatile secretion of $\mathrm{LH}$ and that the specific opioid antagonist, naloxone or naltrexone, reverses this impairment $(12,13)$. Therefore, EOPs may be involved in the 2-B4O-induced decrement in LH secretion.

In this study, to clarify the mechanism of impairment of the hypothalamic function by 2-B40, we examined the hypothesis that 2-B40 may suppress the pulsatile secretion of LH through EOPs. 


\section{Materials and methods}

\begin{abstract}
Animals
Adult female Wistar-Imamichi rats (250-300 g) were purchased from Dohhan Ken (Saitama, Japan). They were housed in a room with controlled lighting (lights on between 0800 and $2030 \mathrm{~h}$ ) and temperature $\left(24^{\circ} \mathrm{C}\right)$ and were given free access to standard laboratory pellets of rat chow and tap-water. All rats were ovariectomized (ovx) bilaterally under i.p. anesthesia with pentobarbital sodium (Nembutal, Abbot Laboratories, North Chicago, IL, USA; $40 \mathrm{mg} / \mathrm{kg}$ body weight) $2-4$ weeks before each experiment.
\end{abstract}

\section{Implantation of brain cannula}

Three weeks after ovariectomy, a brain cannula was implanted under i.p. pentobarbital anesthesia $(50 \mathrm{mg} /$ $\mathrm{kg}$ body weight). A small hole was made in the skull with an electric drill. A guide cannula made of a 23gauge stainless-steel tube $(20 \mathrm{~mm}$ long, $0.64 \mathrm{~mm}$ o.d., $0.39 \mathrm{~mm}$ i.d.) was implanted into the third ventricle (3V) using the stereotaxic coordinates $A P=-1.5$ and $\mathrm{L}=0.0 \mathrm{~mm}$ with respect to the bregma and $\mathrm{H}=7.5-$ $8.0 \mathrm{~mm}$ from the brain surface, according to the atlas of Paxinos \& Watson (14). Two screws in the skull were used to anchor the cannula with dental cement. A sterile 29-gauge stainless-steel obturator with a polyethylene cap (18 mm long, $0.33 \mathrm{~mm}$ o.d.) was inserted into the guide cannula to ensure that the cannula remained patent. A new 29-gauge stainless-steel tube (18 mm long, $0.33 \mathrm{~mm}$ o.d., $0.17 \mathrm{~mm}$ i.d.) connected through a long polyethylene tube $(0.6 \mathrm{~mm}$ o.d.) to a $10 \mu \mathrm{l}$ Hamilton microsyringe that was filled with freshly prepared test solution (2-B4O or saline), was inserted into the guide cannula. The length of the 29-gauge tube was adjusted to reach just to the tip of the guide cannula. Infusion was at a rate of about $1 \mu \mathrm{l} / 10 \mathrm{~s}$, to minimize the intraventricular pressure change. The infusion tube was long enough to permit manipulation of the syringe outside the cage, and to minimize restriction of the rats.

\section{Atrial cannulation}

On the day before the experiment, rats were anesthetized with a mixture of ketamine and xylazine $(20: 5 \mathrm{mg} / \mathrm{kg}$ i.p.) and a silastic tube $(0.94 \mathrm{~mm}$ o.d., $0.51 \mathrm{~mm}$ i.d., Dow-Corning, Midland, MI, USA) was inserted into the external jugular vein and sewn into position in the right atrium (15). The tube was rinsed with heparinized saline (10000 U/l saline) and threaded s.c. to an exit at the back of the neck. On the following day, the intra-atrial cannula was rinsed and connected to a long polyethylene tube containing heparinized saline. A steel pin was inserted into the open end of this tube, which was led outside the cage to permit rapid blood sampling without handling the rats.

\section{Administration of 2-B4O}

$3 \mathrm{~V}$ administration To examine the effect of naloxone on the impaired pulsatility of $\mathrm{LH}$ induced by 2-B4O, on days 7-10 after implantation of the brain cannula unrestrained ovx rats received a $3 \mathrm{~V}$ administration of $5.0 \mu \mathrm{mol} / 2 \mu \mathrm{l} 2-\mathrm{B} 4 \mathrm{O}$ (2(5H)-furanone, Aldrich Chemical Co., Milwaukee, WI, USA) or saline $(2 \mu \mathrm{l})$ only from $1100 \mathrm{~h}$ as previously discribed (11). Blood samples $(0.3 \mathrm{ml})$ were taken every $6 \mathrm{~min}$ for $2 \mathrm{~h}$ through the intra-atrial cannula and an equal volume of heparinized saline containing naloxone (Sigma Chemical Co., St Louis, MO, USA) $(0.5 \mathrm{mg} / \mathrm{kg}$ per h) or heparinized saline only was replaced after each bleeding $(16,17)$. Rats were divided into three experimental groups: group $1,3 \mathrm{~V}$ saline + i.v. saline (control); group 2, 3V 2-B4O+i.v. saline; group 3, 3V 2-B4O + i.v. naloxone. The samples were centrifuged and the plasma was stored at $-40^{\circ} \mathrm{C}$ until required for measurement of $\mathrm{LH}$ concentrations by RIA.

Atrial administration To examine the effect of 2-B40 on expression of pro-opiomelanocortin (POMC) mRNA in the arcuate nucleus, ovx rats (2 weeks after ovariectomy) were cannulated on the day before the experiment. On the experimental day 2-B40 (100 mg/ $\mathrm{kg}$ body weight) dissolved in $0.5 \mathrm{ml}$ saline or saline only was slowly injected through the intra-atrial catheter between 1330 and $1400 \mathrm{~h}$. Animals were killed by decapitation $240 \mathrm{~min}$ after injection and the brains were rapidly removed from the skull, frozen on dry ice, and kept at $-80^{\circ} \mathrm{C}$ until sectioned. There were two rats in each treatment group.

\section{RIA of LH}

Serum LH was measured by double-antibody RIA (18) using a rat LH RIA kit obtained from NIDDK and the National Hormone and Pituitary Program. Values are expressed relative to those for the reference preparation (NIDDK-rLH-RP-3). The minimal detectable dose of this assay was $0.02 \mathrm{ng} /$ tube and the intra- and interassay coefficients of variation (CV) were $8.6 \%$ and $9.2 \%$ respectively.

LH pulses were defined and identified exactly using established criteria as described by DePaolo et al. (19). Briefly, a CV was calculated from LH concentrations on the ascending and descending phase of a suspected pulse. A pulse was defined if the $\mathrm{CV}$ was greater than twice the CV of the LH RIA determined from solutions of LH standards corresponding to the mean LH levels of the suspected pulse. The mean LH pulse amplitude, pulse frequency (number of pulses per $2 \mathrm{~h}$ ) and mean LH levels were calculated for each animal.

\section{Probe preparation of POMC mRNA}

A partial POMC cDNA clone of $423 \mathrm{bp}$, including the entire coding region for $\beta$-endorphin (20), was 
subcloned in Bluescript KS(-). Digoxigenin-labeled sense and antisense RNA probes, corresponding to the POMC mRNA, were synthesized with a commercially available kit (DIG RNA labeling kit; Boehringer Mannheim GMbh, Germany).

\section{In situ hybridization}

Using the atlas of Paxinos \& Watson (14) as an anatomical guide, $14 \mu \mathrm{m}$ coronal sections were cut throughout the rostral arcuate nucleus (bregma 2.3$2.5 \mathrm{~mm}$ ) in a $-15^{\circ} \mathrm{C}$ cryostat and thaw-mounted onto poly-L-lysine-coated slides. Frozen sections were fixed with $4 \%$ paraformaldehyde ( $\mathrm{pH} 7.4$ ) in PBS for $30 \mathrm{~min}$, treated with proteinase-K $(0.25 \mu \mathrm{g} / \mathrm{ml}$ in $10 \mathrm{mM}$ Tris$\mathrm{HCl}$, pH 8.0, and $1 \mathrm{mM}$ EDTA) for $15 \mathrm{~min}$, and fixed again in $4 \%$ paraformaldehyde for $10 \mathrm{~min}$. After a wash with PBS, slides were treated with $0.2 \mathrm{M} \mathrm{HCl}$ for $5 \mathrm{~min}$, and washed again with PBS. Slides were then rinsed in $0.1 \mathrm{M}$ triethanolamine $(\mathrm{pH} 8.0)$, and acetylated with $0.1 \mathrm{M}$ triethanolamine $(\mathrm{pH} \quad 8.0$ ) containing $0.25 \%$ acetic anhydride for $10 \mathrm{~min}$, washed with PBS, sequentially dehydrated in a series of graded ethanol $(70 \%$, $80 \%, 90 \%, 100 \%$ ) and air dried.

After the application of $30 \mu \mathrm{l}$ hybridization solution containing $50 \%$ formamide, $0.6 \mathrm{M} \mathrm{NaCl}, 1 \times$ Denhardt's solution, $0.25 \%$ SDS, $10 \%$ dextran sulfate, $10 \mathrm{mM}$ Tris$\mathrm{HCl}(\mathrm{pH} 7.6), 0.2 \mathrm{mg} / \mathrm{ml}$ yeast transfer RNA (tRNA) and $400 \mathrm{ng} / \mathrm{ml}$ DIG-11-UTP-labeled probe, slides were covered with coverslips and incubated in a moist chamber overnight at $50{ }^{\circ} \mathrm{C}$. After the removal of the coverslips, the slides were rinsed with $50 \%$ formamide $-2 \times$ SSC for $30 \mathrm{~min}$ at $60^{\circ} \mathrm{C}$ and with TNE $(10 \mathrm{mM}$ Tris- $\mathrm{HCl}(\mathrm{pH}$ 7.6), $0.5 \mathrm{M} \mathrm{NaCl}, 1 \mathrm{mM}$ EDTA) for $30 \mathrm{~min}$ at $37^{\circ} \mathrm{C}$. After RNase treatment ( $30 \mu \mathrm{g} / \mathrm{ml}$ RNase-A in TNE) for $30 \mathrm{~min}$ at $37^{\circ} \mathrm{C}$, the slides were rinsed in TNE for $10 \mathrm{~min}$ at $37^{\circ} \mathrm{C}$, in $2 \times \mathrm{SSC}$ and twice in $0.2 \times \mathrm{SSC}$ for $20 \mathrm{~min}$ at $50^{\circ} \mathrm{C}$.

The hybridization signal was detected using a Digoxigenin Detection Kit (Boehringer Mannheim $\mathrm{GmbH})$ according to the manufacturer's instructions. The reaction was stopped by washing for $1 \mathrm{~h}$ in stop buffer (10 mm Tris-HCl (pH 7.6), $1 \mathrm{mM}$ EDTA), and slides were mounted with Crystal/Mount (Biomeda Corp, Foster City, CA, USA).

We processed all 2-B40-treated and control sections together, to ensure that all hybridization and color development conditions were standardized. To demonstrate the specificity of the signals, the following controls were performed: 1) adjacent tissue sections were hybridized with the POMC sense probe and 2) no probe was added to the hybridization solution.

\section{Quantitative analysis of the amount of POMC MRNA}

To determine the time of optimal color development of the hybridization signal in the rostral arcuate nucleus, a time-course study was carried out. At predetermined times (15 and $30 \mathrm{~min}, 1,2$, 3, 5, 7 and $24 \mathrm{~h}$ ), the color development was stopped. The number of tissue sections examined at each time was three. The color intensity of POMC mRNA-positive cells (more than 50 cells each time) in the rostral arcuate nucleus was measured using a computerized image-analysis system as described below.

Three photographs of the arcuate nucleus region $(\times 400$ magnification) in each tissue section were taken under bright-field illumination with a model BH-2 optical microscope (Olympus Optical, Tokyo, Japan) equipped with a camera (Olympus C-35AD-4, Tokyo, Japan), using positive film (Fujichrome Sensia Daylight 100, Fuji Film Corp, Japan). The films were digitized using a scanner (QuickScan 35, Minolta, Japan) with a Macintosh computer Quadra 800 and stored as an array of gray levels from 0 (white) to 256 (black). The stored signals were quantified with a computerized image-analysis program (NIH Image 1.59). The background gray level signal value was subtracted from the intensity of each POMC-positive cell. This corrected color intensity of each cell was averaged over replicates for each animal and used as an index of the relative cellular level of POMC mRNA.

\section{Statistical analysis}

The LH RIA data were analyzed with one-way analysis of test variance, followed by Fisher's protected least significance difference (PLSD) test. All results are presented as means \pm S.E.M.

Statistical significance between results from 2-B4Otreated and control rats in the quantitative analysis of POMC mRNA was evaluated with Student's $t$-test, using $P<0.05$ for the level of significance.

\section{Results}

\section{Effect of naloxone on impaired pulsatility of LH by 2-B4O}

Representative profiles of serum LH in ovx rats treated with $3 \mathrm{~V}$ administration of 2-B4O or saline and sequential i.v. administration of naloxone or saline are depicted in Fig. 1. The mean pulse amplitude of $\mathrm{LH}$, the pulse frequency of $\mathrm{LH}$ and the mean $\mathrm{LH}$ concentrations are shown in Fig. 2. There were no significant differences in the mean LH concentrations (group 1: $3.31 \pm 0.34 \mu \mathrm{g} / \mathrm{l}$, group 2: $2.94 \pm 0.34 \mu \mathrm{g} / \mathrm{l}$, group 3: $3.19 \pm 0.33 \mu \mathrm{g} / \mathrm{l}$; $P<0.1$ ) and the mean LH amplitude (group 1: $4.13 \pm 0.31 \mu \mathrm{g} / \mathrm{l}$, group 2: $3.77 \pm 0.82 \mu \mathrm{g} / \mathrm{l}$, group 3: $2.70 \pm 0.52 \mu \mathrm{g} / \mathrm{l})$ among the three groups. However, the $3 \mathrm{~V}$ administration of 2-B4O significantly suppressed the frequency of pulses (group 2: $1.5 \pm 0.33$ pulses/ $2 \mathrm{~h}$, group 1: $2.43 \pm 0.2$ pulses $/ 2 \mathrm{~h} ; P<0.05)$ and intermittent administration of naloxone significantly 

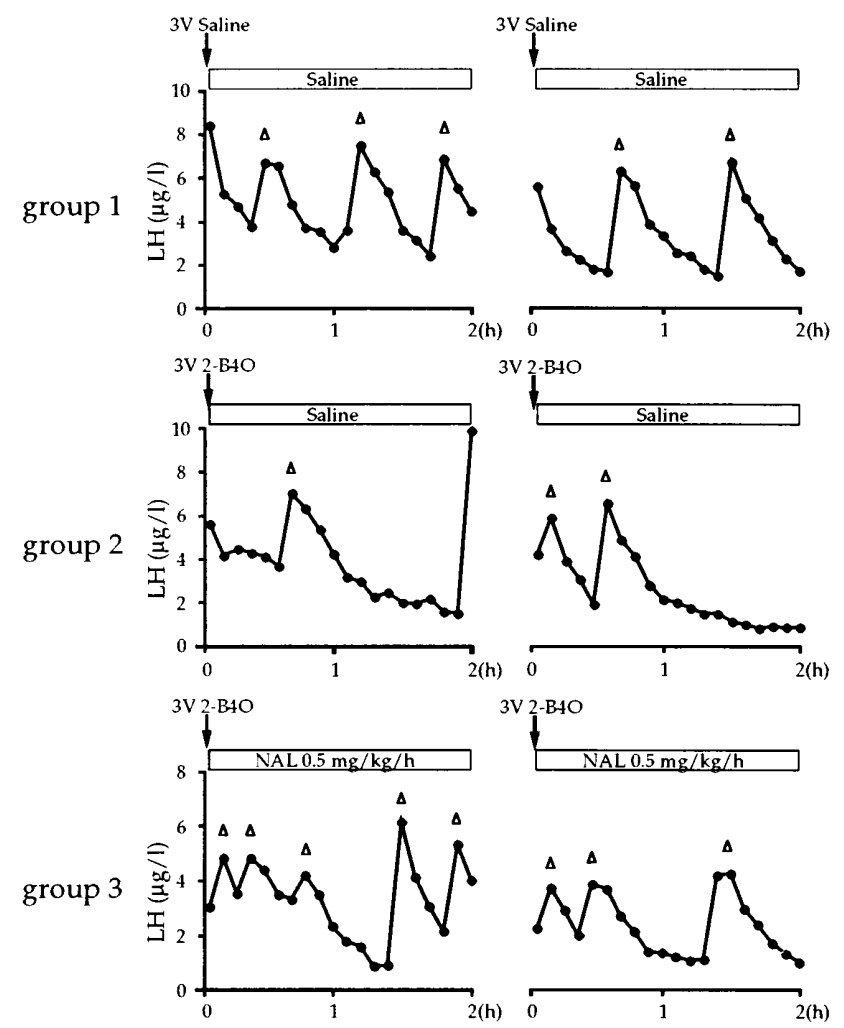

Figure 1 Effect of third cerebroventricle (3V) administration of 2-buten-4-olide (2-B4O) and sequential i.v. administration of naloxone (NAL) on pulsatile release of LH in ovx rats: profiles of rats that received $3 \mathrm{~V}$ injection of $2-\mathrm{B} 4 \mathrm{O}(5.0 \mu \mathrm{mol} / 2 \mu \mathrm{l})$ or saline $(2 \mu \mathrm{l})$ at $0 \mathrm{~min}$ and sequential i.v. injections of naloxone $(0.5 \mathrm{mg} / \mathrm{kg}$ per $\mathrm{h}$ ) or saline every $6 \mathrm{~min}$ for $2 \mathrm{~h}$. The rats were bled every $6 \mathrm{~min}$ for $2 \mathrm{~h}$. Group 1: 3V saline + i.v. saline (control); group 2: 3V 2$\mathrm{B} 4 \mathrm{O}+\mathrm{i} . v$. saline; group 3: $3 \mathrm{~V} 2-\mathrm{B} 4 \mathrm{O}+\mathrm{i} . \mathrm{v}$. naloxone. $\triangle$, pulse of $\mathrm{LH}$ secretion.

restored the frequency of pulses (group 3: $3.29 \pm 0.36$ pulses $/ 2 \mathrm{~h}$, group 2: $1.5 \pm 0.33$ pulses $/ 2 \mathrm{~h} ; \mathrm{P}<0.01$ ). There was no significant difference in the frequency between groups 1 and 3 .

\section{Effect of 2-B4O on expression of POMC mRNA in the arcuate nucleus}

Figure 3 depicts an example of the data obtained by in situ hybridization. Hybridization with the DIG-labeled antisense RNA probe yielded specific staining in the rostral arcuate nucleus (Fig. 3, top), whereas hybridization with the DIG-labeled sense RNA probe did not generate staining (Fig. 3, bottom). Specific staining was not observed without the probe being added to the hybridization solution (data not shown).

The relationship between the color intensity of the hybridization signal and color development time in rat rostral arcuate nucleus was investigated by a timecourse study; the results are shown in Fig. 4. The intensity of the color signal concentrated within POMC
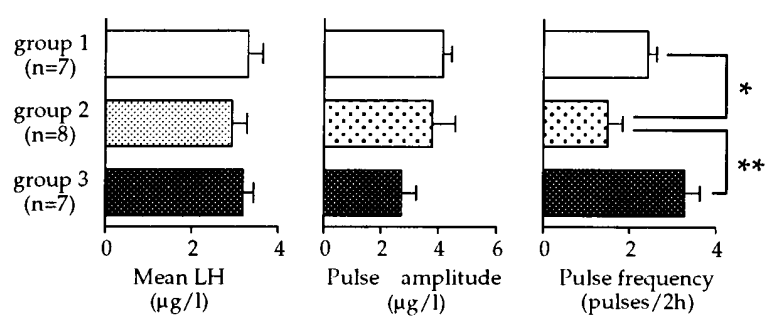

Figure 2 Effect of third cerebroventricle (3V) administration of 2-buten-4-olide (2-B4O) and sequential i.v. administration of naloxone on pulsatile release of LH in ovx rats. On days 7-10 after implantation of a brain cannula, at $1100 \mathrm{~h}$, rats received a $3 \mathrm{~V}$ injection of $2-\mathrm{B} 4 \mathrm{O}(5.0 \mu \mathrm{mol} / 2 \mu \mathrm{l})$ or saline $(2 \mu \mathrm{l})$ at $0 \mathrm{~min}$ and sequential i.v. injections of naloxone $(0.5 \mathrm{mg} / \mathrm{kg}$ per $\mathrm{h})$ or saline every $6 \mathrm{~min}$ at bleeding time for $2 \mathrm{~h}$. Group 1: $3 \mathrm{~V}$ saline +i.v. saline (control); group 2: 3V 2-B4O + i.v. saline; group 3: 3V 2-B4O + i.v. naloxone. Values are expressed as means \pm S.E.M. ${ }^{*} P<0.05$ compared with group $1,{ }^{\star \star} P<0.01$ compared with group 3 (oneway analysis of test variance, followed by Fisher's protected least significance difference test).

mRNA-positive cells was found to increase up to $3 \mathrm{~h}$ and plateaued after that. It was important to ensure that all quantitative measurements were made while the curve was rising, therefore $30 \mathrm{~min}$ and 1,2 and $3 \mathrm{~h}$ color development times were selected for the quantitative study.

Figure 5 depicts photomicrographs at each color development time that show the POMC mRNA positivecells in the rostral arcuate nucleus of 2-B4O-treated and control rats. Analysis of POMC mRNA concentrations in individual cells of the rostral arcuate nucleus by a computerized image-analysis system revealed that 2-B4Otreated rats had a significant increase at all color development times compared with control rats (Fig. 6). There was no significant difference in the number of POMC positive cells between 2-B40-treated and control rats.

\section{Discussion}

We have demonstrated that 2-B4O, which is an endogenous sugar acid and a feeding suppressant, impairs the pulsatile secretion of LH. We reported previously (10) that chronic i.p. treatment with 2-B40 disturbs the estrous cycle and diminishes the serum LH concentrations in intact rats. Moreover, we reported (11) that administration of 2-B40 via i.p., i.v. $(100 \mathrm{mg} / \mathrm{kg})$ and $3 \mathrm{~V}(5 \mu \mathrm{mol})$ routes, in doses that decrease food intake, suppresses the pulsatile secretion of LH in ovx rats, and especially the pulse frequency. These results indicate that 2-B4O reduces LH pulsatile secretion. The pulsatile secretion of $\mathrm{LH}$ is known to be mediated by the $\mathrm{GnRH}$ pulse (21), therefore, 2-B4O may affect the hypothalamic function in ovx rats. However, its mechanism is unknown.

In our previous studies $(10,11)$, rats receiving chronic i.p. administration of $2-\mathrm{B} 40$ had weight gains 


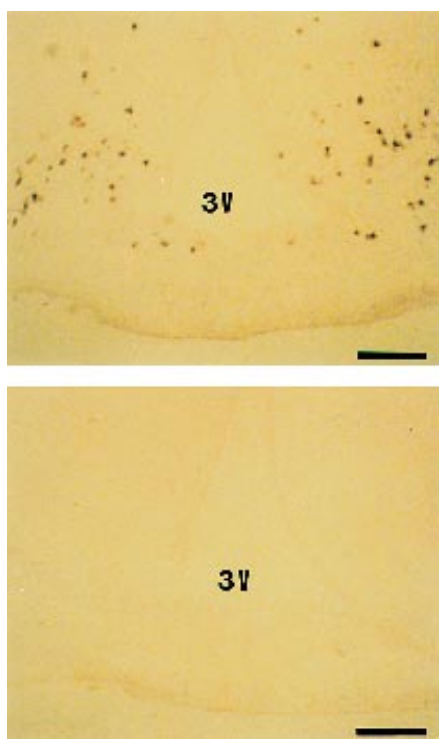

Figure 3 Photomicrographs showing the rostral periarcuate region ( $\times 100$ magnification) after hybridization with a digoxigeninlabeled antisense probe (top) and a digoxigenin-labeled sense probe (bottom). 3V, third cerebroventricle. Scale bar represents $100 \mu \mathrm{m}$.

similar to those of control rats. This finding suggests that 2-B4O may not have suppressed pulsatile secretion of LH through body weight loss. Next, we speculated that two factors might contribute to the impairment of GnRH secretion from the hypothalamus by 2-B40: corticotropin releasing factor (CRF) and EOPs. We investigated CRF in a previous study (11), but found that pretreatment with 10 or $50 \mu \mathrm{g}$ CRF antagonist did not block the suppressive effect of 2-B4O. This finding suggested that 2-B40 might not suppress the pulsatile

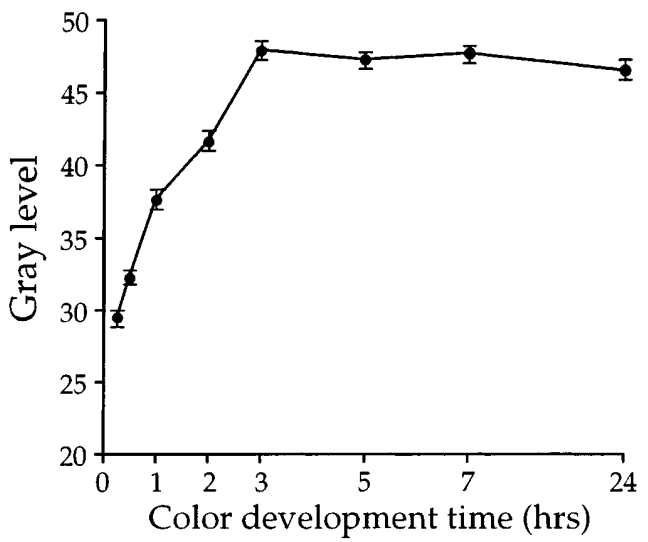

Figure 4 Relationship between the color intensity of the hybridization signal (gray level) and color development time in the rat rostral arcuate nucleus. Note that the intensity of the hybridization signal increases with color development time until approximately $3 \mathrm{~h}$, after which it begins to plateau. Values are expressed as means \pm S.E.M. More than 50 cells were sampled at each time. secretion of LH through the CRF pathway. In the present study, we investigated whether EOPs were involved in the suppression of LH pulsatility.

There is general agreement that EOPs exert a suppressive effect on $\mathrm{LH}$ secretion. There are also several reports that fasting impairs the pulsatile secretion of LH $(3-5)$ and that specific opioid antagonists reversed this impairment $(12,13)$. Therefore, EOPs might be involved in the 2-B4O-induced decrease in LH. The effect of 2-B4O on pulsatile secretion of $\mathrm{LH}$ cannot be analyzed clearly using adult female rats with ovaries because it may be affected by ovarian factors such as estradiol, progesterone, inhibin and activin. In our previous study (11), we found that the $3 \mathrm{~V}$ administration of 2-B4O suppressed LH secretion most strongly. Therefore, we used ovx rats and the $3 \mathrm{~V}$ route to administer 2-B40.

The present results demonstrated that $3 \mathrm{~V}$ administration of 2-B4O suppressed the pulse frequency of $\mathrm{LH}$, as in our previous study, and intermittent administration of naloxone $(0.5 \mathrm{mg} / \mathrm{kg}$ per $\mathrm{h})$ after $3 \mathrm{~V}$ administration of 2-B4O restored the pulse frequency. Funabashi et al. (16) reported that, in ovx rats, intermittent administration of naloxone in the same dose as we used resulted in a significant increase in the mean LH concentration. Kimura et al. (17) reported that the same intermittent administration of naloxone in ovx rats significantly increased the frequency and the duration of multiunit activity volleys that accompanied the initiation of each LH pulse. In the present study, naloxone did not increase the mean LH concentrations; therefore, the suppressive effect of 2-B4O on the pituitary response to GnRH might not be completely blocked by administration of naloxone. In contrast, naloxone restored the pulse frequency of $\mathrm{LH}$ secretion. This finding suggests that 2-B4O suppresses the GnRH release through EOPs.

$\beta$-Endorphin, which is an endogenous opioid peptide, is secreted by processing the precursor, POMC. The greatest concentration of POMC-derived peptides has been found in the arcuate nucleus (22). It has been suggested (23-26) that the POMC neurons from the arcuate nucleus to the medial preoptic area participate, either directly or indirectly via $\mu$ receptors, in the inhibition of GnRH neuronal activity. Bohler et al. (27), using radioactive in situ hybridization (ISH), reported that the pattern of changes in POMC mRNA concentrations in the rostral periarcuate region was consistent with an inhibitory effect of $\beta$-endorphin on $\mathrm{GnRH}$ release. Therefore, we studied whether 2-B40 increased the biosynthesis of POMC mRNA within the rostral arcuate nucleus.

Larsen \& Mau (28), using radioactive ISH and a computerized image-analysis system (NIH image ver 1.49), reported that, $240 \mathrm{~min}$ after initiation of the restraint stress, POMC mRNA concentrations within the arcuate nucleus were significantly increased. A computerized image-analysis system has also been reported (29) to be useful for quantitative non-radioactive ISH 

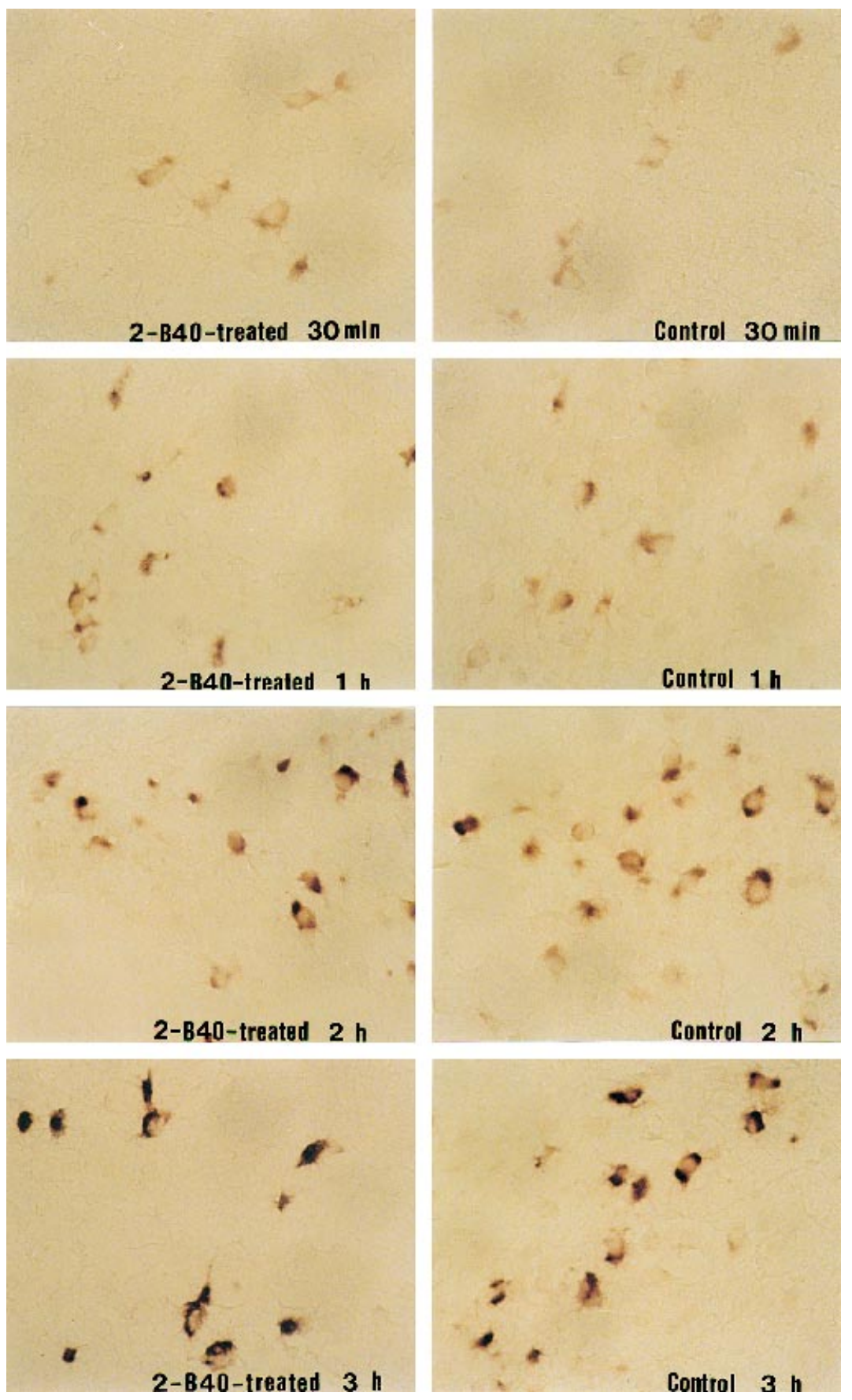

Figure 5 Photomicrographs showing POMC mRNA-positive cells in rostral arcuate nucleus ( $\times 400$ magnification) of 2-B4O-treated (left) and control rat (right) at $30 \mathrm{~min}$ and 1 , 2 and $3 \mathrm{~h}$.

with a digoxigenin-labeled probe. Therefore, to measure the POMC mRNA concentrations in the rostral arcuate nucleus $240 \mathrm{~min}$ after i.v. injection of 2-B4O $(100 \mathrm{mg} / \mathrm{kg})$, we used non-radioactive ISH with a digoxigenin-labeled probe and a computerized image-analysis system (NIH image $1.59 /$ fat).
The present results demonstrate that the administration of 2-B4O also significantly increased the POMC mRNA concentrations within the rostral arcuate nucleus. Although the content and release of EOPs were not directly determined, this finding suggests that 2-B4O increases the biosynthesis of EOPs. 


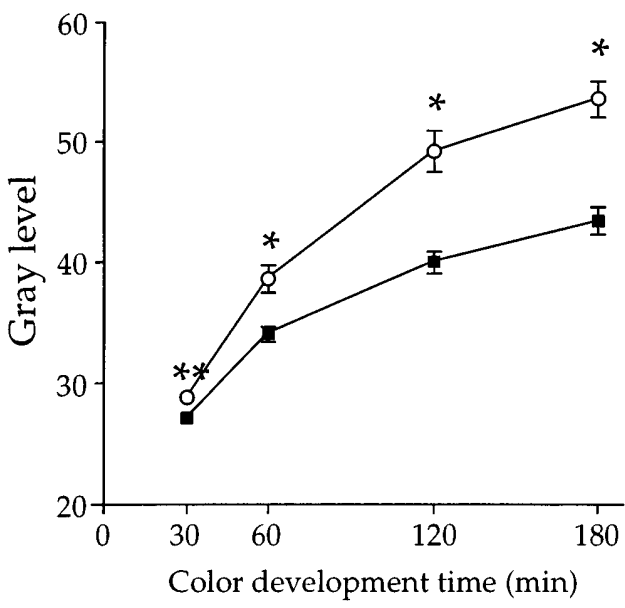

Figure 6 Color intensity of the hybridization signal (gray level) in the rostral arcuate nucleus of 2-B4O-treated and control rats at $30 \mathrm{~min}$ and 1,2 and $3 \mathrm{~h}$. Note that the intensity of the hybridization signal in POMC-mRNA positive cells was significantly increased in 2-B4Otreated rats at all times. O, 2-B4O-treated rats; $\mathbf{\square}$, saline treatedcontrol rats. Values are expressed as means \pm S.E.M. More than 50 cells were sampled at each time. ${ }^{*} P<0.01$ compared with saline control, ${ }^{\star \star} P<0.05$ compared with saline control (Student's $t$-test).

In conclusion, these results indicate that 2-B40 may impair GnRH release by activating the opioid pathway, and increases in 2-B40 and EOPs in the hypothalamus may contribute to starvation-induced reproductive dysfunction.

\section{Acknowledgements}

We are indebted to the NIDDK and the National Hormone and Pituitary Program (University of Maryland School of Medicine) for supplying the rat LH RIA kit. This work was partially supported by a grant from the Research Group on Anorexia Nervosa, sponsored by the Japanese Ministry of Health and Welfare.

\section{References}

1 Perloff WH, Lasch'e EM, Nodine JH, Schneeberg NG \& Vieillard CB. The starvation state and functional hypopituitarism. Journal of the American Medical Association 1954155 1307-1313.

2 Warren MP, Jewelewicz R, Dyrenfurth I, Ans R, Khalaf S \& VandeWiele RL. The significance of weight loss in the evaluation of pituitary response to LH-RH in women with secondary amenorrhea. Journal of Clinical Endocrinology and Metabolism $197540601-611$

3 Campbell GA, Kurcz M, Marshall S \& Meites J. Effects of starvation in rats on serum levels of follicle stimulating hormone, luteinizing hormone, thyrotropin, growth hormone and prolactin; response to LH-releasing hormone. Endocrinology 1977100 580-587.

4 Knuth UA \& Friesen HG. Starvation induced anestrous; effect of chronic food restriction on body weight, its influence on oestrous cycle and gonadotropin secretion in rats. Acta Endocrinologica 1983104 402-409.

5 Bergendahl M, Perheentupa A \& Huhtaniemi IT. Effect of shortterm starvation on reproductive hormone gene expression, secretion and receptor levels in male rats. Journal of Endocrinology 1989121 409-417.

6 Oomura Y. Newly characterized C-chain organic acids for neuronal control of food intake. Biomedical Research 19845 (Suppl) 91-104.

7 Shimizu N, Oomura Y \& Sakata T. Modulation of feeding by endogenous sugar acids acting as hunger or satiety factors. American Journal of Physiology 1984246 R 542-R550.

8 Sakata T, Arase K, Fujimoto K, Kurata K, Fukunaga K, Fukushima M, Steffens AB \& Oomura Y. Structural characteristics of endogenous sugar acids and relations to feeding modulation. Brain Research 1988473 51-59.

9 Plata-Salaman CR, Oomura Y \& Shimizu N. Endogenous sugar acid derivative acting as a feeding suppressant. Physiology and Behavior 198638 359-373.

10 Shitsukawa K, Irahara M, Kanematsu T, Azuma K \& Aono T. Effect of 2-buten-4-olide, an endogenous suppressant of feeding, on reproductive function in rats. Acta Endocrinologica 1990123 571-576.

11 Saito S, Shitsukawa K, Irahara M, Matsuzaki T \& Aono T. Effects of 2-buten-4-olide, an endogenous feeding suppressant, on the pulsatile secretion of luteinizing hormone in ovariectomized rats. Acta Endocrinologica $1993129467-472$.

12 Briski KP, Quigley K \& Meites J. Endogenous opiate involvement in acute and chronic stress-induced changes in plasma LH concentrations in the male rat. Life Sciences 198434 2485-2493.

13 Dyer RG, Mansfield H, Corbet H \& Dean ADP. Fasting impairs LH secretion in female rats by activating an inhibitory opioid pathway. Journal of Endocrinology 1984105 91-97.

14 Paxinos G \& Watson C. The Rat Brain in Stereotaxic Coordinates. Australia: Academic Press Australia, 1982.

15 Harms PG \& Ojeda SR. A rapid and simple procedure for chronic cannulation of the rat jugular vein. Journal of Applied Physiology $197436391-392$.

16 Funabashi T, Kato A \& Kimura F. Naloxone affects the luteinizing hormone secretory pattern in the short- and long-term ovariectomized rat. Neuroendocrinology 199052 35-41.

17 Kimura F, Nishihara M, Hiruma H \& Funabashi T. Naloxone increases the frequency of the electrical activity of luteinizing hormone-releasing hormone pulse generator in long-term ovariectomized rats. Neuroendocrinology 199153 97-102.

18 Monroe SE, Parlow AF \& Midgley AR Jr. Radioimmunoassay for rat luteinizing hormone. Endocrinology 196883 1004-1012.

19 DePaolo LV, King RA \& Carrillo AJ. In vivo and in vitro examination of an autoregulatory mechanism for luteinizing hormonereleasing hormone. Endocrinology $1987120272-279$.

20 Oates E \& Herbert E. 5' Sequence of porcine and rat proopiomelanocortin mRNA. Journal of Biological Chemistry 1984 $2597421-7425$.

21 Knobil E. The endocrine control of the menstrual cycle. Recent Progress in Hormone Research 198036 53-88.

22 Mezey E, Kiss JZ, Mueller GP, Eskay R, O’Donohue TL \& Palkovits M. Distribution of the pro-opiomelanocortin derived peptides, adrenocorticotrope hormone, $\alpha$-melanocyte-stimulating hormone and $\beta$-endorphin (ACTH, $\alpha$-MSH, $\beta$-END) in the rat hypothalamus. Brain Research 1985328 341-347.

23 Thind KK \& Goldsmith PC. Infundibular gonadotropin-releasing hormone neurons are inhibited by direct opioid and autoregulatory synapses in juvenile monkeys. Neuroendocrinology 198847 203-216.

24 Chen WP, Witkin JW \& Silverman AJ. Beta-endorphin and gonadotropin-releasing hormone synaptic input to gonadotropinreleasing hormone neurosecretory cells in the male rat. Journal of Comparative Neurology 1989286 85-95.

25 Leranth C, MacLusky NJ, Shanabrough M \& Naftolin F. Immunohistochemical evidence for synaptic connections between proopiomelanocortin-immunoreactive axons and LH-RH neurons in preoptic area of the rat. Brain Research 1988449 167-176.

26 Lynch DR \& Snyner SH. Neuropeptides: multiple molecular forms, metabolic pathways and receptors. Annual Review of Biochemistry 198655 723-799. 
27 Bohler HCL Jr, Tracer H, Merriam GR \& Petersen SL. Changes in proopiomelanocortin messenger ribonucleic acid levels in the rostral periarcuate region of the female rat during the estrous cycle. Endocrinology 1991128 1265-1269.

28 Larsen PJ \& Mau SE. Effect of acute stress on the expression of hypothalamic messenger ribonucleic acids encoding the endogenous opioid precursors preproenkephalin A and proopiomelanocortin. Peptides 199415 783-790.
29 Robbins E, Baldino F Jr, Roberts-Lewis JM, Meyer SL, Grega D \& Lewis ME. Quantitative non-radioactive in situ hybridization of preproenkephalin mRNA with digoxigenin-labeled cRNA probes. Anatomical Record 1991231 559-562.

Received 2 April 1997

Accepted 25 August 1997 